\title{
ATC Enhancement Considering Transient Stability by Optimal Power Flow Control Using UPFC
}

\author{
Taisuke Masuta Student Member (The University of Tokyo, masuta@syl.t.u-tokyo.ac.jp) \\ Hiroaki Motoki Member (The University of Tokyo, motokinet@tokyo.email.ne.jp) \\ Akihiko Yokoyama Member (The University of Tokyo, yokoyama@syl.t.u-tokyo.ac.jp)
}

Keywords: power system, available transfer capability (ATC), FACTS, UPFC, transient stability, optimal power flow

In recent years it has been necessary to open the available capacity of transmission network to the third party due to open access to transmission systems for transaction in the deregulated environment. Transmission lines are limited resources, which have various physical constraints such as thermal capacity, stability, voltage limits. Available Transfer Capability (ATC) is limited by such constraints. To transfer more power through the network, investment of new transmission line and control equipment is necessary. However, the cost of new transmission lines is very expensive. In addition, there is a problem of right of way.

With recent development of power electronics technology, power system stability enhancement and optimal power flow (OPF) control by using Flexible AC Transmission System (FACTS) devices have so far been studied. The FACTS devices to relieve such multiple constraints can also make it possible to enhance ATC without construction of new transmission lines. Though transmission system reinforcement is essential in the long term in order to maintain reliability in spite of deregulation, it is expected that the progress of the power electronics technology will make the cost of FACTS devices much cheaper than that of such transmission lines.

In this paper, a new method for improving transient stability by using Unified Power Flow Controller (UPFC), one of FACTS devices which is composed of two inverters, Static Synchronous Compensator (STATCOM) and Static Synchronous Series Compensator (SSSC), is proposed. Then the proposed method is applied to an OPF control method by using UPFC for relieving multiple constraints. The new OPF method is used for enhancement of ATC taking into account stability constraints as well as overload and steady-state stability constraints.
Table 1. ATC considering transient stability

\begin{tabular}{|c|c|c|}
\hline $\begin{array}{c}\text { ATC without UPFC } \\
(\text { MW) }\end{array}$ & $\begin{array}{c}\text { ATC with UPFC } \\
\text { (MW) }\end{array}$ & $\begin{array}{c}\Delta \text { ATC } \\
(\text { MW) }\end{array}$ \\
\hline 2950 & 4740 & 1790 \\
\hline
\end{tabular}

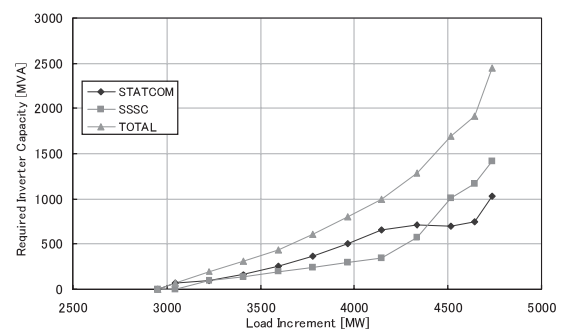

Fig. 1. Load increment vs inverter capacity

The optimal controller of UPFC is designed to improve transient stability as well as steady-state stability, and the operating parameters of UPFC are also determined to alleviate transmission line congestions. From an economic viewpoint, the OPF problem is formulated to minimize total capacity of inverters of UPFC.

The proposed method is examined with single UPFC installation in 10-machine 47-bus system. ATC without UPFC and ATC with $\mathrm{UPFC}$ in one wheeling case (G6 $\rightarrow$ L43) are shown in Table 1 . The transition of inverter capacity in its case is graphed in Fig. 1. It is made clear that ATC is enhanced by relieving not only static constraints such as .transmission line congestions but also dynamic constraints such as steady-state stability and transient stability by UPFC controlled based on the proposed OPF method. 


\title{
UPFCを用いた最適潮流制御による過渡安定度を考慮した ATC 拡大手法の基礎的検討
}

\author{
学生員 益田 泰輔* 正 員 元木 啓明* \\ 正員 横山 明彦*
}

\section{ATC Enhancement Considering Transient Stability by Optimal Power Flow Control Using UPFC}

Taisuke Masuta*, Student Member, Hiroaki Motoki*, Member, Akihiko Yokoyama*, Member

\begin{abstract}
With recent development of power electronics technology, power system stability enhancement and optimal power flow control by using Flexible AC Transmission System (FACTS) devices have so far been studied. The FACTS devices to relieve multiple constraints can also make it possible to enhance Available Transfer Capability (ATC) without construction of new transmission lines. In this paper, a new method for improving transient stability by Unified Power Flow Controller (UPFC) is proposed. Then the proposed method is applied to an OPF control method by using UPFC for relieving multiple constraints. The new OPF method is used for enhancement of ATC taking into account Transient stability constraints as well as overload and steady-state stability constraints. The OPF problem is formulated to minimize total capacity of inverters of UPFC. Effectiveness of the proposed method is shown by numerical examples for IEEJ East-10-machine test system.
\end{abstract}

キーワード : 電力システム, ATC, FACTS, UPFC, 過渡安定度, 最適潮流計算

Keywords: power system, ATC, FACTS, UPFC, transient stability, optimal power flow

\section{1. はじめに}

近年，電力自由化に伴う送電ネットワークのオープンア クセス化により，託送に必要な送電線の空き容量が公開さ れている。この送電線は限られた資源であり, 熱容量・安 定度・電圧といった種々の物理的制約による送電容量限界 が存在する。また，熱的潮流制約といった静的な制約だけ でなく，定態安定度や過渡安定度などの動的な制約によっ ても送電可能な電力は制限される。従って送電ネットワー クにはこれらの制約に違反する潮流を流すことはできず, それ以上に電力を流したい場合には容量拡張のための新規 設備投資が必要となる。

そのような設備投資の 1 つとして, 新規送電線建設と並ん で自励式インバータを応用した FACTS (Flexible AC Transmission Systems) 機器の利用の可能性がある。FACTS 機 器を用いることで, 新規の送電線を建設することなく既存の 送電網を最大限活用して安定度向上や送電線の熱的潮流制 約などの解消を行うことが可能である (1) (3)。今後のパワー

\footnotetext{
東京大学大学院

干 113-8656 東京都文京区本郷 7-3-1

Dept. of Electrical Eng., University of Tokyo

7-3-1, Hongo, Bunkyo-ku, Tokyo 113-8656
}

エレクトロニクス技術の進歩により FACTS 機器の利用が より経済的となる可能性が期待され, FACTS 機器を用いた ATC (Available Transfer Capability) の拡大手法も検討さ れている (4)(5)。応答速度の遅い移相変圧器などによる潮流制 御機能だけでATCを拡大しようとすると, 安定度で制限さ れてしまう場合もあるが，パワーエレクトロニクス技術を 応用した応答速度の速い FACTS 機器は潮流制御だけでな く安定度向上も同時に行うことが可能であり，それ 1 台で 複数の制約を同時に解消して ATC 拡大に寄与できる ${ }^{(6)(7)}$ 。 本研究では, 電力系統の流通設備である送電ネットワー クの能力を表す ATCについて, これを向上させるため, 柔 軟な潮流制御が可能な FACTS 機器である UPFC (Unified Power Flow Controller) をとりあげる。UPFC は SSSC, STATCOM という直並列のインバー夕機器から構成されて おり, 直並列を同時に用いた動作だけでなく, 直列側の SSSC だけでの動作, 並列側の STATCOM だけでの動作も可能で ある。本研究で UPFCを用いた理由は, このように一台の UPFC でこれらの 3 つの機器の動作を模擬することが可能 であり, 設置容量の最適化により, 必ずしもUPFCではな くSSSC PSTATCOM で十分な場合もあることも見ること ができるためである。

ATC 拡大のための設備投資は, 誰がその費用負担をする 
かは議論のあるところではあるが，負担の可能性のある消 費者またはその利用したい系統内の事業者にとってできる だけコスト最小なものでなければならない。本研究では, この公平性の議論の前に，まずできるだけ費用負担を最小， つまり設備容量を最小にした UPFCによるATC 拡大の可 能性について検討する必要があると考え，これまでの静的 な熱的潮流制約, 動的な定態安定度制約(6)に加え, 動的な 過渡安定度制約 ${ }^{(8)}$ を考慮し，できるだけ少ないインバー夕 設置容量で ATC を最大限拡大する最適潮流制御の手法を 提案し，その手法を大規模モデル系統に適用しその効果を 検証する。

\section{ATCについて}

$\langle\mathbf{2} \cdot \mathbf{1}\rangle$ ATC の定義 ATC は, 北米電力信頼度協議会 ${ }^{(9)}$ (NERC : North American Electric Reliability Council) の定 義によると,「電力系統において信頼性を損なうことなくあ る地点から別の地点に向かってすべての経路を介して送電 を行う際の送電可能容量」のことである。ATC は系統内の 多数の想定事故点での単一事故を考慮した上で 2 地点間に 追加的に送電可能な電力とも言える。NERCによると ATC は次式で計算される。

$$
A T C=T T C-T R M-C B M-T C
$$

ATC は, 全送電可能容量 TTC (Total Transfer Capability) から TRM (Transmission Reliability Margin), CBM (Capacity Benefit Margin）といったマージンおよびTC (Transmission Commitments）を差し引いて計算する。TRMとは 不確実性に対応して確保すべきマージン, CBM は連系系統 で供給予備力を確保するために必要なマージンであり，TC はベース潮流を含む。

本研究ではマージンは考えず，送電限界電力からベース 潮流を引いた次式を ATCとして考えている。

$$
A T C=T T C-T C
$$

〈2・2〉ATCの分類 ATCは最終的にどの制約条件で 送電限界が決まるかによって安定度 ATC, 電圧 ATC, 潮 流 ATC の 3 つに分類される (6)。安定度 ATC は微小擾乱に 対して系統が発散しない定態安定度によるATC と大きな 事故に対して系統が脱調しない過渡安定度によるATCに 分けられる。電圧 ATC では系統が電圧違反を起こさない で送電できる限界によって決まる静的な電圧限界と, 動的 な電圧崩壊現象である電圧安定度も考慮される。潮流 ATC は送電線の物理的熱容量限界（熱的潮流制約）によって決 まるATCである。

\section{UPFC の解析モデルおよび制御系}

〈3・1〉 UPFC の構成 UPFC は代表的な FACTS 機器 の一つであり，Fig. 1 のように送電線に直・並列にインバー 夕を持つ。このためUPFC は直並列機器とも呼ばれる。ま た, 2 台のインバータの直流部分は共通のコンデンサで接続

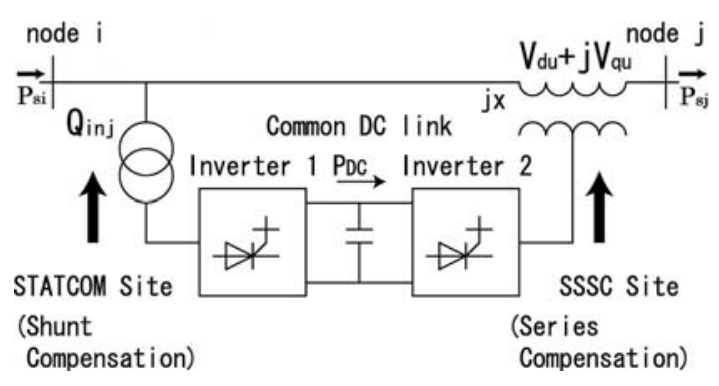

Fig. 1. Configuration of UPFC.

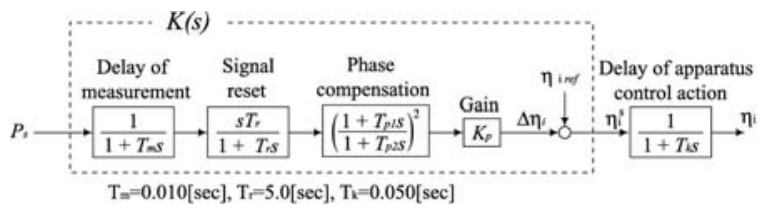

Fig. 2. PSS-type controller of UPFC.

されているのでインバータ間で自由に有効電力の融通が可 能である。UPFC は系統に電圧 $\mathrm{V}_{\mathrm{du}}+\mathrm{j} \mathrm{V}_{\mathrm{qu}}$, 無効電力 $\mathrm{Q}_{\mathrm{inj}}$ を印加し, 柔軟な潮流制御を行う。本研究ではUPFC の等 価モデルとして node $\mathrm{j}$ の電圧のベクトル方向に新たな座標 軸 $\mathrm{d}$ 軸を定義し，Fig. 1 の $\mathrm{V}_{\mathrm{du}}, \mathrm{V}_{\mathrm{qu}}, \mathrm{Q}_{\mathrm{inj}}$ の 3 つを操作変 数 $\eta^{(10)}$ とした。

〈3.2〉 UPFC の制御系 本研究では各 UPFC の操作 変数に対して, Fig. 2 のような PSS タイプのゲイン・位相 補償制御系を用いてローカル制御を行う(10) ことを仮定して いる。この制御系は, 設置送電線通過有効電力 $\mathrm{P}_{\mathrm{s}}$ を制御 入力としてその変動を抑えるよう制御する。定態安定度向 上 ${ }^{(6)(11)}$ を目的としたこの制御系のゲインを適切に決定する ことで過渡安定度も同時に向上可能な手法を提案する。

\section{4. 過渡安定度を考慮した ATC 算出手法}

$\langle\mathbf{4} \cdot \mathbf{1}\rangle$ ATC 拡大のための最適潮流制御のアルゴリズム UPFC を用いてできるだけ少ない総インバー夕設置容量 でATCを最大化するためのアルゴリズムを Fig. 3 に示す。 本手法は，潮流制御 (6)，定態安定度向上制御(6)(11)，過渡安 定度向上制御 ${ }^{(8)}$ の 3 つの部分から構成される。ある経路の ATC を考える際, 受電側の負荷を微少量増加させていくと, 何らかの系統制約違反が発生する場合がある。この違反が もし熱的潮流制約違反であれば「潮流制御」を，定態安定 度制約違反であれば「定態安定度向上制御」を呼び出し制 御を行う。こうして, UPFC の操作变数・制御系パラメー 夕を決定変数として動かすことで制約が解消され ATC 増大 が可能となる場合，その值に更新する。これで定常状態に おける UPFC の容量および各パラメータが決定される (の)。 (定常状態では何も制約違反を起こさないならこの時点で操 作変数・制御系パラメー夕を変更することはない。）定常状 態の運用状況が決まった後, 各ノードで三相地絡事故を起 


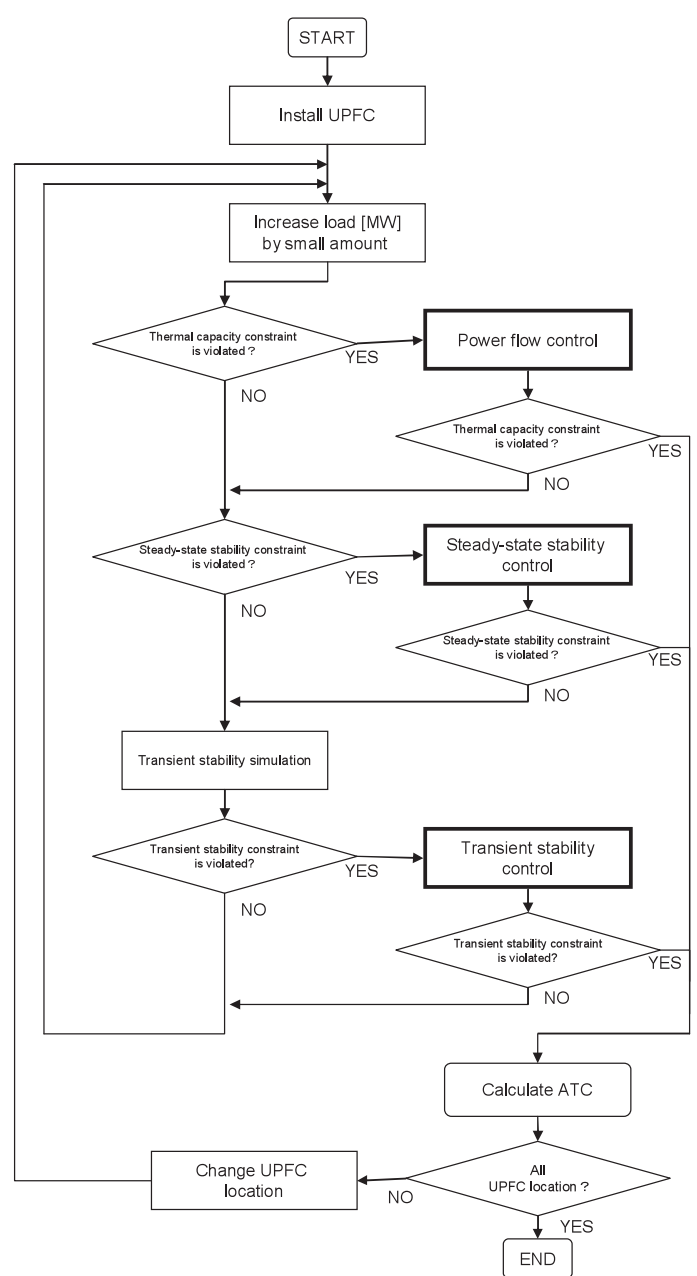

Fig. 3. Flow chart of OPF considering transient stability.

こして過渡シミュレーションを行う。もし過渡安定度が保 たれない場合は「過渡安定度向上制御」を呼び出す。これ によって過渡安定度の制約が解消された場合，すべての制 約が解消され，託送電力を増加できるのでさらに負荷を微 少量増加させ同様の操作を行う。これを制約違反解消がで きなくなるまで続けることでATC が求められる。

$\langle\mathbf{4} \cdot \mathbf{2}\rangle$ 潮流制御潮流制御 (6) は, UPFC の設置容量 を最小化する線形計画法の最適化問題を解いている。この 最適化問題の決定変数はUPFC の操作変数 $\eta$ であり, 目的 関数は (3) 式で, 制約条件は (4) (9) 式である。この段階 では安定度制約条件は設けていない。安定度に対しては潮 流制御が終わった段階で制御系のパラメータを操作するこ とにより対策を行う。潮流制御に扔いては特に N-1 ルール を考慮している。

(目的関数)

$$
P Q_{\text {statcom } \max }+P Q_{\text {sssc } \max } \rightarrow \min
$$

（定常時における潮流に関する方程式）

$$
I^{(k)}=y^{(k)} V^{(k)}
$$

(潮流制約)

$$
P_{j}^{(k)}\left(\eta^{(k)}\right) \leq P_{j \max } \quad(j \in B, k \in A)
$$

（電圧制限）

$$
V_{i \min } \leq V_{i}\left(\eta^{(k)}\right) \leq V_{i \max } \quad(i \in N)
$$

（1 回線開放時に抢ける UPFC の定格容量制限）

$$
\begin{aligned}
& V_{U}^{(k)}\left(\eta^{(k)}\right) \leq V_{U} \max \\
& P Q_{\text {sssc }}^{(k)}(x(t)) \leq P Q_{\text {sssc max }} \ldots \ldots \ldots \\
& P Q_{\text {statcom }}^{(k)}(x(t)) \leq P Q_{\text {statcom } \max } \cdots \cdots
\end{aligned}
$$
ただし，

$\mathrm{PQ}_{\text {statcom, }} \mathrm{PQ}_{\mathrm{sssc}}$ : $\mathrm{UPFC}$ の各インバータの皮相電力

$\mathrm{PQ}_{\text {statcom max }}, \mathrm{PQ}_{\text {sssc } \max }$ : UPFC の各インバー夕 の皮相電力の定格

$P_{\mathrm{j}}:$ 送電線 $\mathrm{j}$ の通過有効電力

$P_{\mathrm{j} \text { max }}$ : 送電線 $\mathrm{j}$ の熱容量上限

$\mathrm{V}_{\mathrm{i}}, \mathrm{V}_{\mathrm{i} \max }, \mathrm{V}_{\mathrm{i} \text { min }}$ :ノード $\mathrm{i}$ の電圧とその上下限

$\mathrm{V}_{\mathrm{U}}, \mathrm{V}_{\mathrm{U} \text { max }}$ : UPFC の印加電圧とその定格

$\mathrm{x}:$ 電力系統の動的要素

$\mathrm{y}:$ 系統のアドミタンス行列

$\mathrm{V}, \mathrm{I}$ ：ノードの電圧，電流

$\mathrm{B}:$ すべての送電線の集合

A：すべての事故ケースの集合

各变数添え字 $(\mathrm{k})$ は事故ケース $\mathrm{k}=1,2, \cdots \mathrm{N}$ の場合を示す。

$\langle\mathbf{4} \cdot \mathbf{3}\rangle$ 定態安定度向上制御 定態安定度向上制御 (6) では, 定態安定度を示す電力システムの線形化モデルの固 有值を左半平面に動かす際に固有值感度の計算を行い，パ ラメータの移動が最も少なくてすむようにパラメー夕を動 かすという操作量準最小化アルゴリズム(11)を用いている。 制御の際, 線形性を崩さないように 1 回の制御を 20 回の ステップに分けて段階的に行っている。安定限界は固有值 が左半平面にあることとした。なお，制御の際，UPFCの 操作変数 $\eta$ を用いて安定化させることも可能であるが, 設 置容量最小化のためにはなるべく操作変数を使わない方が 好ましい。本研究では, 操作変数を使わずに制御系のパラ メータのみで定態安定度向上を行っている。

$\langle\mathbf{4} \cdot \mathbf{4}\rangle$ 過渡安定度向上制御の前提条件本研究での 過渡安定度の定義拈よび過渡解析の留意点について説明す る。ある経路の ATC を段階的に増加していった潮流状態 ごとに 5 秒間の過渡シミュレーションを行って安定度を検

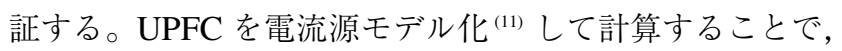
UPFC を系統に導入しての過渡シミュレーションを行うこ とができる。

（1）想定事故および過渡安定度の評価法事故はノー ド至近端に扔ける三相地絡事故を考え，第一波脱調するか しないかを過渡安定度の評価基準とする。第一波脱調しな 
い最大の事故継続時間を CCT (Critical Clearing Time) とし て定義し, CCT をある基準時間以上確保できればその潮流状 態では過渡的に安定とし，確保できないなら不安定とする。 CCT の基準は $200[\mathrm{~ms}]$ とする（簡単のため, $200[\mathrm{~ms}]$ 後に 線路開放による事故除去拉よび再閉路を行うものとする)。

（2）事故点のスクリーニング 全ノードについて事 故が起こる可能性があるので, 事故点は複数存在する。そ の中で最も過酷な事故点を見つけることが重要である。一 般に最過酷ポイントでの事故において過渡安定度を保つこ とができれば他の点での事故でも過渡安定度は保たれるか らである。また，UPFCを通過する皮相電力も事故が厳し くなるほど大きくなると考えられるので，UPFC の設置容 量も大きくなると予想される。UPFC の設置位置または託 送経路の違いや，ATCを計算する過程で潮流を重くしてい く過程で, 動作点がどんどん変わっていくので，厳密に言 うと最過酷事故点は一つには決まらない。本研究では, ま ず過渡安定度を調べたい潮流状態においてすべてのノード で三相地絡事故を起こして CCT を調べ，最も CCT が小さ くなるノードを最過酷事故点としてその点での事故を解消 できるかどうかに焦点を絞る。

（3）事故中・事故後の UPFC 動作 事故継続時間中 および事故除去後 $20[\mathrm{~ms}]$ までUPFC は停止する。（操作変 数 $\mathrm{V}_{\mathrm{du}}, \mathrm{V}_{\mathrm{qu}}, \mathrm{Q}_{\mathrm{inj}}$ 全て 0 とし, 系統状態は UPFC の漏れリ アクタンスのみ考える。）事故復帰後 20 [ms] で UPFC を投 入し，投入直後の操作変数はすべて 0 とする。

$\langle\mathbf{4} \cdot 5\rangle$ 過渡安定度向上制御 ノード至近端三相地絡事 故のうち最過酷事故点について過渡安定度向上のためUPFC の制御系パラメータを決定するプログラムを提案する。過 渡シミュレーション時, 操作変数の動きに直接効いてくる Fig. 2 の制御系のパラメータはゲイン $\mathrm{K}_{\mathrm{p}}$ であり, このプ ログラムでは操作変数 $\mathrm{V}_{\mathrm{du}}, \mathrm{V}_{\mathrm{qu}}, \mathrm{Q}_{\mathrm{inj}}$ それぞれについて最 も過渡安定度を向上させられる 3 つのゲイン $\mathrm{K}_{\mathrm{p}}$ の值を決 める。UPFC の操作変数 $\mathrm{V}_{\mathrm{du}}, \mathrm{V}_{\mathrm{qu}}, \mathrm{Q}_{\mathrm{inj}}$ の初期值は定常状 態で潮流制約を満たすものを用いるものとし, 制御系パラ メータ $\mathrm{K}_{\mathrm{p}}$ は過渡安定度を満たすものを選ぶ方針とする。こ の後固有值をチェックして, 過渡安定度を改善する $\mathrm{K}_{\mathrm{p}}$ の 組み合わせが定態安定度を満たすかどうかを再確認する。

Fig. 4 に $\mathrm{K}_{\mathrm{p}}$ を決定するアルゴリズムを示す。 3 つの 操作変数に対する $\mathrm{K}_{\mathrm{p}}$ のどれか 1 つを微小変化させてそ れぞれの場合の CCT を調べ, 最も CCT 感度が大きいも の（最大 CCT 変化量のもの）に $\mathrm{K}_{\mathrm{p}}$ の值を更新していく。 例えば定常状態の $\mathrm{K}_{\mathrm{p}}$ の組を $\left(\mathrm{K}_{\mathrm{p} 0}[1], \mathrm{K}_{\mathrm{p} 0}[2], \mathrm{K}_{\mathrm{p} 0}[3]\right)$ とし たとき，この状態から 1 つのゲインを微小に変化させた $\left(\mathrm{K}_{\mathrm{p} 0}[1] \pm \Delta, \mathrm{K}_{\mathrm{p} 0}[2], \mathrm{K}_{\mathrm{p} 0}[3]\right), \quad\left(\mathrm{K}_{\mathrm{p} 0}[1], \mathrm{K}_{\mathrm{p} 0}[2] \pm \Delta, \mathrm{K}_{\mathrm{p} 0}[3]\right)$, $\left(\mathrm{K}_{\mathrm{p} 0}[1], \mathrm{K}_{\mathrm{p} 0}[2], \mathrm{K}_{\mathrm{p} 0}[3] \pm \Delta\right)$ の 6 通りの組を考える。6つの 組でそれぞれ過渡シミュレーションを行い, 最も CCTが大 きくなった組に $\mathrm{K}_{\mathrm{p}}$ を更新していく。同じ $\mathrm{CCT}$ となる $\mathrm{K}_{\mathrm{p}}$ の組が複数存在する場合は, UPFC のインバー夕設置容量 (過渡シミュレーション時に UPFC を通過する皮相電力の 最大值）が最小となるものを選ぶ(準最小化)。

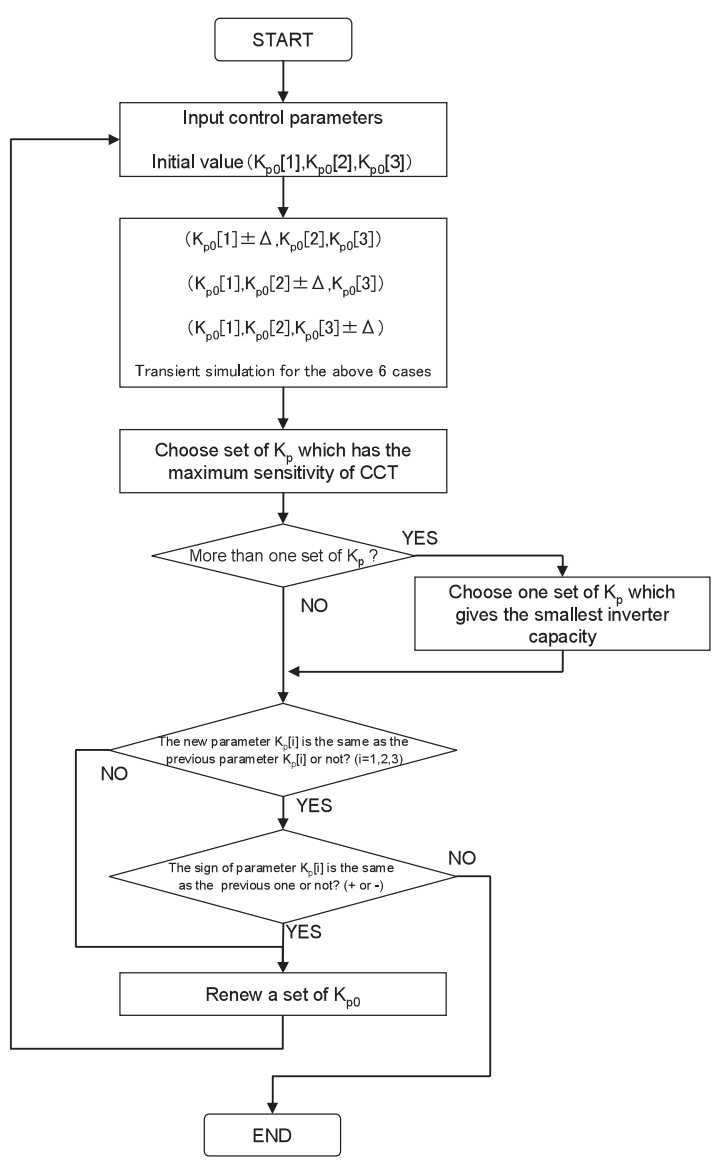

Fig. 4. Flow chart of determining control parameter.

\section{10 機 47 母線系統におけるシミュレーション}

これまでに，最も簡単なループ系統である 3 機 9 母線系 統（100MVA ベース）でUPFCを用いた最適潮流制御を 行って熱的潮流制約や定態安定度制約だけでなく過渡安定

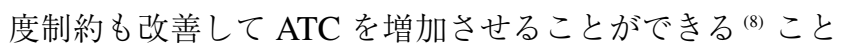
を確認した。本論文では, さらに大規模な系統において, 特定の経路の ATC を向上させるシミュレーションを行う。 Fig. 5 の電気学会東 10 機系統モデルに UPFC を設置し, 最 適潮流制御による ATC 拡大手法を適用した。

〈5・1 シミュレーション条件 文献 (1)の先行研究で は, 電気学会東 10 機系統モデル (1000 MVA ベース) に おいて次の 3 つの託送ケースを例として取り上げ, 過渡安 定度制約は考えず，熱的潮流制約および定態安定度制約の みを考えた UPFCによる最適潮流制御を用いた ATC 拡大 の効果を確認している(日)。括弧内の数字はその場合の最大 ATC を確保できた UPFC 設置送電線の番号を示す。つま り, 熱的潮流制約と定態安定度制約を解消する目的で最適 な設置位置である。

（1）発電機 $06 \rightarrow$ 負荷 $43 （ 34 ） \cdots$ 近距離託送ケース

（2）発電機 $10 \rightarrow$ 負荷 $38 （ 38 ） \cdots \cdot$ 遠距離託送ケース

（3）発電機 $02 \rightarrow$ 負荷 $41 （ 20 ） \cdots$ 中距離託送ケース

本研究では電気学会東 10 機系統モデルに㧍けるこれら 3 つの託送ケースについて, 新たに $4 \cdot 1\rangle$ 節の過渡安定度向 


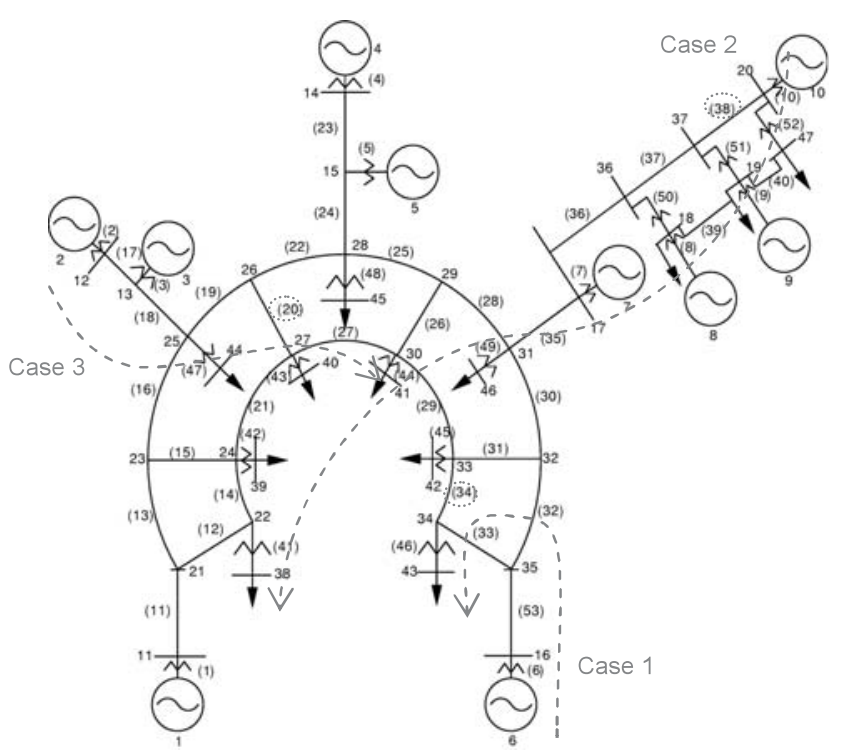

Fig. 5. IEEJ east 10 model.

上制御を含む最適潮流制御を適用して, 過渡安定度制約も 考慮したATC を計算した。

UPFC の過渡安定度向上効果は限定的なものであり，す べての事故ケース，託送ケースに 1 台の UPFC で対応する のは難しい(8)。また，UPFCには送電線の熱的潮流制約解 消と定態安定度向上いう機能がまずあって, 付加的な機能 として過渡安定度向上に用いるのが妥当である(8)。そこで 本研究では, UPFC の使い方の基本的検討として 3 つの託 送ケースそれぞれについて，熱的潮流制約解消と定態安定 度向上の観点からみて最適な位置（括弧内の番号の送電線） にUPFC を設置するとして，その設置位置で過渡安定度向 上制御を行い，過渡安定度も考慮したATC を計算し，その 効果について検討を行うこととした。過渡安定度について は，事故は注目する経路の発電機ノード至近端での三相地 絡事故が最も厳しいのでその事故について過渡安定度向上 制御を行った。

〈5·2〉 シミュレーション結果

（1）近距離託送ケース 発電機 6 只負荷 43 への 託送ケースについて，UPFCを送電線 34 に設置したときの ATC を計算した。Table 1, Table 2 に, 熱的潮流制約・定 態安定度制約のみを考え, 過渡安定度制約を考慮しないと きの ATC および設置容量を示す。このケースは定態安定 度制約には違反することなく, 潮流制約を解消しきれなく なって ATCが決まっている。

過渡安定度も考慮したATC の計算結果を Table 3, Table 4 に示す。Table 4 の $\Delta$ ATC/Capacity とは, Table 3 の ATC 増分を Table 4 の UPFC のインバー夕総設置容量で割った 単位容量あたりの ATC 増分を示す。過渡安定度向上制御 の対象事故はノード 6 の三相地絡事故をとした。

託送電力を増加させていくとまず過渡安定度制約が現れ， さらに託送電力を大きくすると送電線の熱的潮流制約にも 違反し, 2 つの制約をUPFCで解消している。最終的な ATC
Table 1. ATC not considering transient stability $(\mathrm{G} 6 \rightarrow \mathrm{L} 43)$.

\begin{tabular}{|c|c|c|}
\hline $\begin{array}{c}\text { ATC without UPFC } \\
\text { (MW) }\end{array}$ & $\begin{array}{c}\text { ATC with UPFC } \\
\text { (MW) }\end{array}$ & $\begin{array}{c}\Delta \text { ATC } \\
(\mathrm{MW})\end{array}$ \\
\hline 4590 & 5800 & 1210 \\
\hline
\end{tabular}

Table 2. Required capacities of inverters of UPFC for ATC on Table 1.

\begin{tabular}{|c|c|c|}
\hline \multicolumn{3}{|c|}{ Required Capacities(MVA) } \\
\hline STATCOM & SSSC & Total \\
\hline 220 & 270 & 490 \\
\hline
\end{tabular}

Table 3. ATC considering transient stability (G6 $\rightarrow$ L43).

\begin{tabular}{|c|c|c|}
\hline $\begin{array}{c}\text { ATC without UPFC } \\
\text { (MW) }\end{array}$ & $\begin{array}{c}\text { ATC with UPFC } \\
\text { (MW) }\end{array}$ & $\begin{array}{c}\Delta \text { ATC } \\
\text { (MW) }\end{array}$ \\
\hline 2950 & 4740 & 1790 \\
\hline
\end{tabular}

Table 4. Required capacities of inverters of UPFC for ATC on Table 3.

\begin{tabular}{|c|c|c|c|}
\hline \multicolumn{2}{|c|}{ Required Capacities(MVA) } & \multirow{2}{*}{$\begin{array}{c}\text { A ATC/Capacity } \\
\text { (MW/MVA) }\end{array}$} \\
\hline STATCOM & SSSC & Total & \\
\hline 10300 & 14200 & 24500 & 0.073 \\
\hline
\end{tabular}

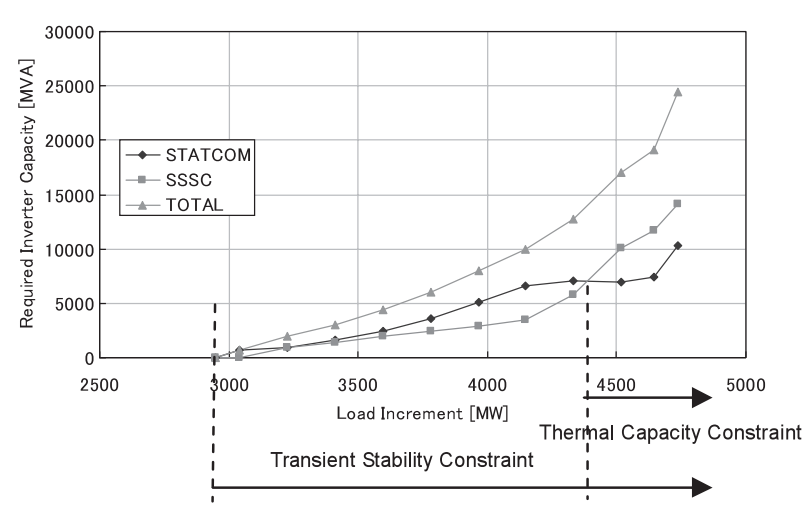

Fig. 6. Load increment vs inverter capacity (UPFC on branch $34, \mathrm{G} 6 \rightarrow \mathrm{L} 43$ ).

は過渡安定度制約で決まっている。

次に, 過渡安定度も考慮した場合の UPFC のインバー夕 設置容量, 操作変数の定常值, 制御系ゲインの推移をそれ ぞれ Fig. 6〜 Fig. 8 に示す。

託送電力が小さいときはSTATCOM 側の容量が SSSC 側 より大きく必要とされる傾向があるが, 託送電力が大きくな るにつれて SSSC 側の容量の増え方も大きくなり, 潮流制 約違反解消が始まる託送電力を超えると SSSC 側が STAT$\mathrm{COM}$ 側より大きな容量が必要とされる。Fig. 8 から, $\mathrm{V}_{\mathrm{du}}$, $\mathrm{V}_{\mathrm{qu}}$ のゲインの絶対值と比べて, $\mathrm{Q}_{\mathrm{inj}}$ のゲインが大きいこと が分かる。 $\mathrm{V}_{\mathrm{du}}, \mathrm{V}_{\mathrm{qu}}, \mathrm{Q}_{\mathrm{inj}}$ が定常值を持たないときはいず れのゲインの絶対值も単調に増加しているが, 熱的潮流制 約に違反して定常值を持った後はそうならなくなっている。

（2）遠距離託送ケース 発電機 10 から負荷 38 への 託送ケースについて, UPFCを送電線 38 に設置したとき の ATC を計算した。Table 5, Table 6 に, 熱的潮流制約・ 定態安定度制約のみを考え, 過渡安定度制約を考慮しない ときの ATC 㧍よび設置容量を示す。このケースは潮流制 


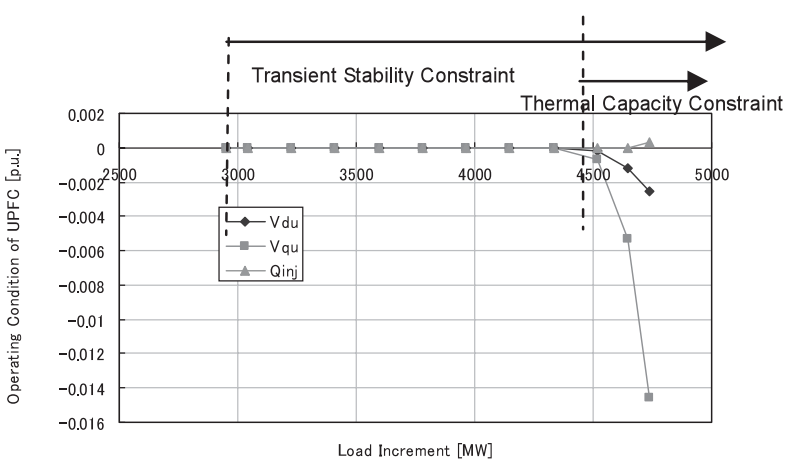

Fig. 7. Load increment vs operating condition of UPFC (UPFC on branch 34 , G6 $\rightarrow$ L43).

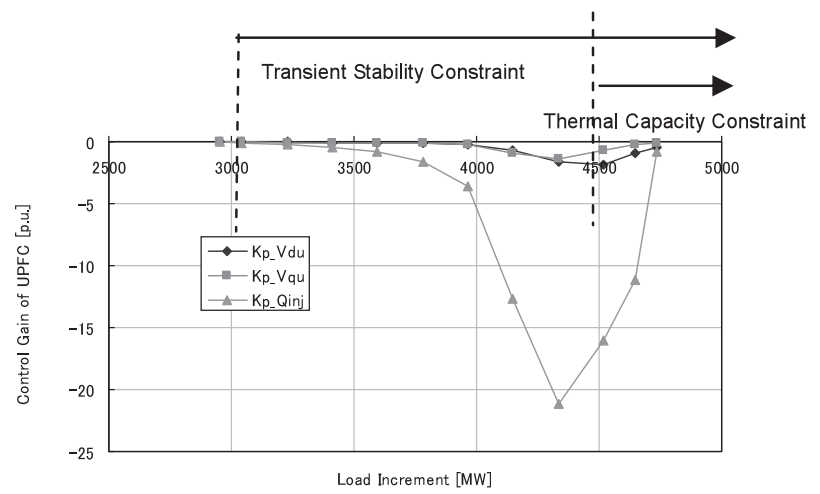

Fig. 8. Load increment vs control gain of UPFC (UPFC on branch 34 , G6 $\rightarrow$ L43).

Table 5. ATC not considering transient stability $(\mathrm{G} 10 \rightarrow \mathrm{L} 38)$

\begin{tabular}{|c|c|c|}
\hline $\begin{array}{c}\text { ATC without UPFC } \\
(\mathrm{MW})\end{array}$ & $\begin{array}{c}\text { ATC with UPFC } \\
(\mathrm{MW})\end{array}$ & $\begin{array}{c}\Delta \text { ATC } \\
(\mathrm{MW})\end{array}$ \\
\hline 1490 & 2620 & 1130 \\
\hline
\end{tabular}

Table 6. Required capacities of inverters of UPFC for ATC on Table 5.

\begin{tabular}{|c|c|c|}
\hline \multicolumn{3}{|c|}{ Required Capacities(MVA) } \\
\hline STATCOM & SSSC & Total \\
\hline 0 & 0 & 0 \\
\hline
\end{tabular}

約には違反することなく，定態安定度制約が解消しきれな くなって ATCが決まっている。必要設置容量が 0 なのは, UPFC の操作変数 $\mathrm{V}_{\mathrm{du}}, \mathrm{V}_{\mathrm{qu}}, \mathrm{Q}_{\mathrm{inj}}$ ではなく制御変数 $\mathrm{K}_{\mathrm{P}}, \mathrm{T}_{\mathrm{P}}$ を変更するのみで定態安定度を改善しているためである。

過渡安定度も考慮したATC の計算結果を Table 7, Table 8 に示す。過渡安定度向上制御の対象事故はノード 10 の三相 地絡事故とした。託送電力を増加させていくとまず過渡安 定度制約が現れ，他の制約が現れる前に過渡安定度制約に よって最終的な ATC が決まっている。Table 4 の近距離託 送ケースと比べて単位容量あたりの ATC 増分が大きいが, これは違反する制約が過渡安定度制約のみで, 全ての容量 を過渡安定度向上だけにしか使わないためと考えられる。

次に，過渡安定度も考慮した場合の UPFC のインバー夕 設置容量，制御系ゲインの推移を Fig. 9， Fig. 10 に示す。 熱的潮流制約に違反しないので操作変数の定常値は 0 のま
Table 7. ATC considering transient stability (G10 $\rightarrow$ L38).

\begin{tabular}{|c|c|c|}
\hline $\begin{array}{c}\text { ATC without UPFC } \\
\text { (MW) }\end{array}$ & $\begin{array}{c}\text { ATC with UPFC } \\
\text { (MW) }\end{array}$ & $\begin{array}{c}\Delta \text { ATC } \\
\text { (MW) }\end{array}$ \\
\hline 740 & 1490 & 750 \\
\hline
\end{tabular}

Table 8. Required capacities of inverters of UPFC for ATC on Table 7.

\begin{tabular}{|c|c|c|c|}
\hline \multicolumn{2}{|c|}{ Required Capacities(MVA) } & \multirow{2}{*}{$\begin{array}{c}\text { ATC/Capacity } \\
\text { (MW/MVA) }\end{array}$} \\
\hline STATCOM & SSSC & Total & \\
\hline 5900 & 2400 & 8300 & 0.090 \\
\hline
\end{tabular}

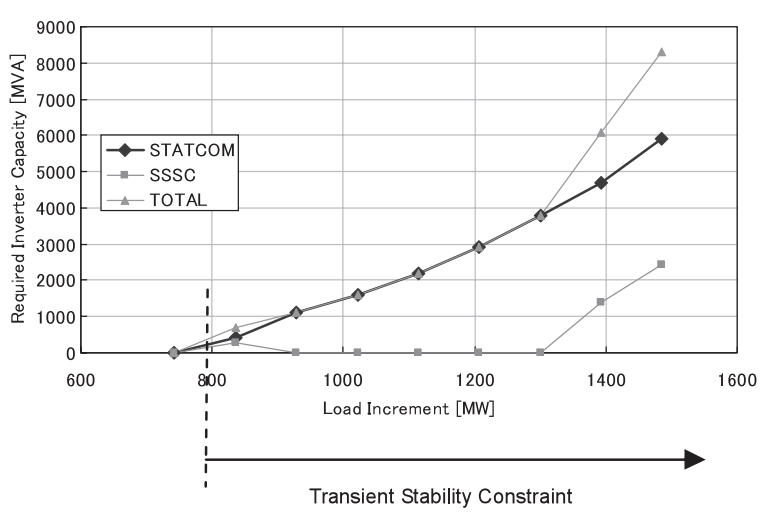

Fig. 9. Load increment vs inverter capacity (UPFC on branch $38, \mathrm{G} 10 \rightarrow \mathrm{L} 38$ ).

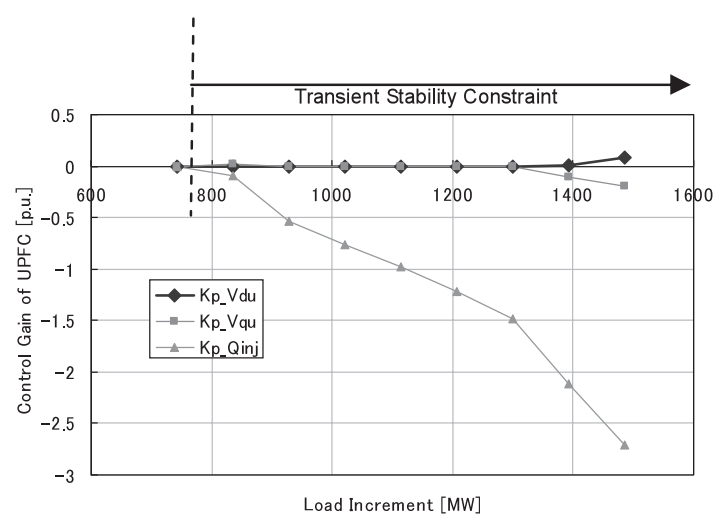

Fig. 10. Load increment vs control gain of UPFC (UPFC on branch 38, G10 $\rightarrow$ L38).

ま変化しない。STATCOM の容量がSSSC より大きく必要 とされる傾向がある。託送電力が大きくなると SSSC の容 量も必要とされる。制御系ゲインの絶対值は, $\mathrm{V}_{\mathrm{du}}, \mathrm{V}_{\mathrm{qu}}$ の ゲインと比べて $\mathrm{Q}_{\mathrm{inj}}$ のゲインが大きく, いずれも単調に増 加している。

（3）中距離託送ケース 発電機 2 から負荷 41 への 託送ケースについて，UPFC を送電線 20 に設置したとき の ATC を計算した。Table 9, Table 10 に, 熱的潮流制約・ 定態安定度制約のみを考え, 過渡安定度制約を考慮しない ときの ATC および設置容量を示す。このケースは託送電 力の増加に伴い，まず潮流制約に違反し UPFCによって制 約違反を解消する。さらに託送電力を増加させると定態安 定度制約にも違反し, 潮流制約と定態安定度制約の 2 つを UPFC で同時に解消して託送電力を確保している。最終的 
Table 9. ATC not considering transient stability $(\mathrm{G} 2 \rightarrow \mathrm{L} 41)$.

\begin{tabular}{|c|c|c|}
\hline $\begin{array}{c}\text { ATC without UPFC } \\
(\mathrm{MW})\end{array}$ & $\begin{array}{c}\text { ATC with UPFC } \\
(\mathrm{MW})\end{array}$ & $\begin{array}{c}\Delta \text { ATC } \\
(\mathrm{MW})\end{array}$ \\
\hline 5600 & 6320 & 720 \\
\hline
\end{tabular}

Table 10. Required capacities of inverters of UPFC for ATC on Table 9.

\begin{tabular}{|c|c|c|}
\hline \multicolumn{3}{|c|}{ Required Capacities(MVA) } \\
\hline STATCOM & SSSC & Total \\
\hline 150 & 660 & 810 \\
\hline
\end{tabular}

Table 11. ATC considering transient stability (G2 $\rightarrow$ L41).

\begin{tabular}{|c|c|c|}
\hline $\begin{array}{c}\text { ATC without UPFC } \\
(\mathrm{MW})\end{array}$ & $\begin{array}{c}\text { ATC with UPFC } \\
(\mathrm{MW})\end{array}$ & $\begin{array}{c}\Delta \text { ATC } \\
(\mathrm{MW})\end{array}$ \\
\hline 4820 & 5630 & 810 \\
\hline
\end{tabular}

Table 12. Required capacities of inverters of UPFC for ATC on Table 11.

\begin{tabular}{|c|c|c|c|}
\hline \multicolumn{2}{|c|}{ Required Capacities(MVA) } & \multirow{2}{*}{$\begin{array}{c}\Delta \text { ATC/Capacity } \\
\text { (MW/MVA) }\end{array}$} \\
\hline STATCOM & SSSC & Total & \\
\hline 6200 & 6700 & 12900 & 0.063 \\
\hline
\end{tabular}

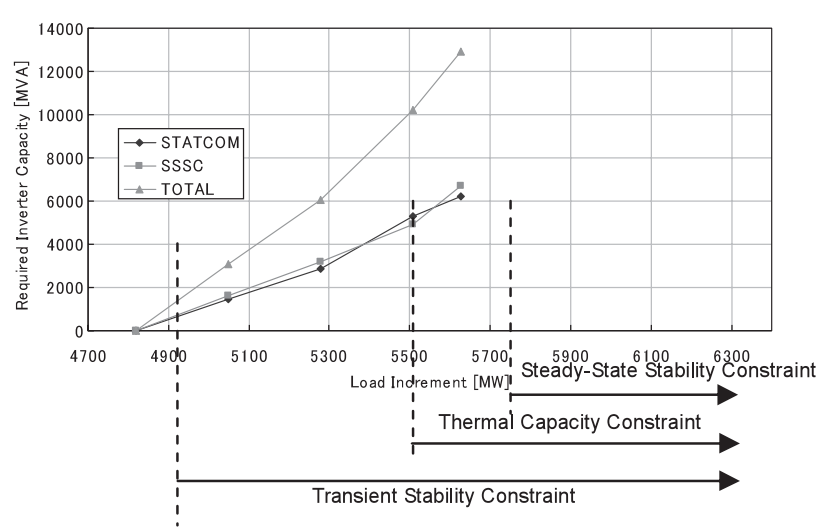

Fig. 11. Load increment vs inverter capacity (UPFC on branch $20, \mathrm{G} 2 \rightarrow \mathrm{L} 41$ ).

に潮流制約が解消しきれなくなって ATCが決まっている。 過渡安定度も考慮した ATC の計算結果を Table 11, Table 12 に示す。過渡安定度向上制御の対象事故はノード 2 の三相地絡事故とした。託送電力増加させていくとまず過 渡安定度制約に違反し, UPFC の過渡安定度向上制御によっ て違反を解消する。託送電力が Table 9 の左の值を超える と熱的潮流制約に違反し，潮流制御と過渡安定度向上制御 を行って違反を解消する。さらに託送電力を増加させると, 定態安定度制約に違反する。ここで，3つの制約を同時に 解消したいが，定態安定度制約違反を解消できる制御系パ ラメータの值では過渡安定度を向上できず，逆に過渡安定 度制約違反を解消できる制御系パラメータの值では固有值 が悪くなり定態安定度を保てないため, この時点の託送電 力がATCとして決まっている。

次に, 過渡安定度も考慮した場合の UPFCのインバータ設 置容量, 操作変数の定常值, 制御系ゲインの推移を Fig. 11 Fig. 13 に示す。どの時点でどの制約が入ってくるか分かる

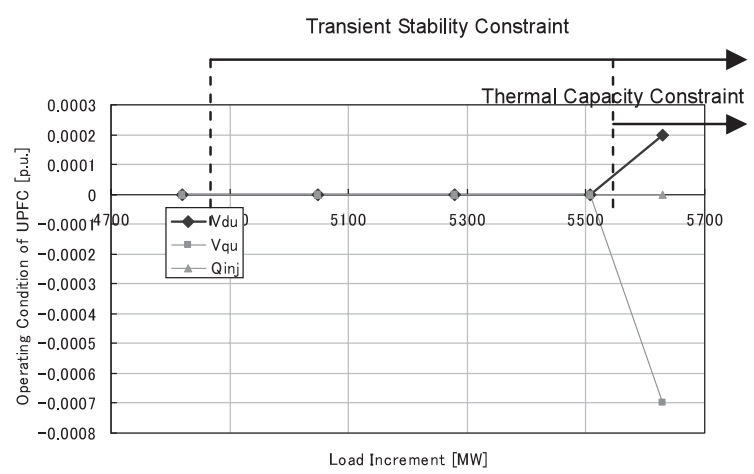

Fig. 12. Load increment vs operating condition of UPFC (UPFC on branch 20, G2 $\rightarrow$ L41).

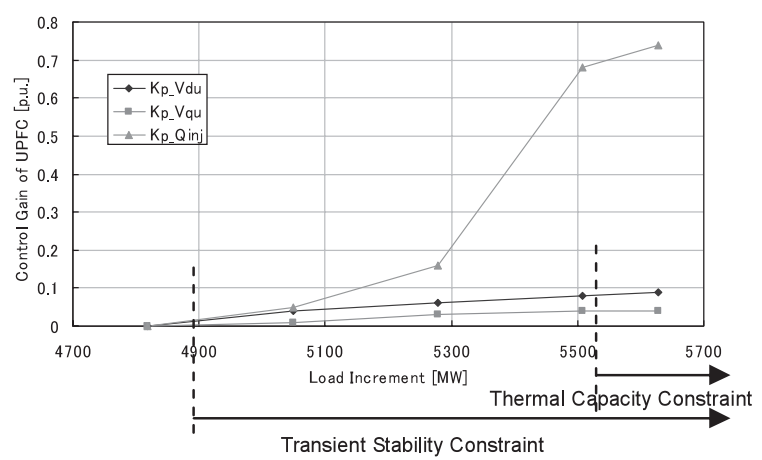

Fig. 13. Load increment vs control gain of UPFC (UPFC on branch 20, G2 $\rightarrow$ L41).

ように Fig. 11 の横軸は実現可能な ATCより大きい值まで 示している。制御系ゲインの絶対值は, $\mathrm{V}_{\mathrm{du}}, \mathrm{V}_{\mathrm{qu}}$ のゲイン と比べて $\mathrm{Q}_{\text {inj }}$ のゲインが大きく, いずれも単調に増加して いるのが分かる。

$\langle\mathbf{5} \cdot \mathbf{3}\rangle$ 考察本論文で提案した UPFC の過渡安 定度向上制御は, 熱的潮流制約違反解消制御とは協調でき るが, 定態安定度向上制御と協調するのは難しい場合がある のが分かった。ここでの過渡安定度向上手法では過渡安定 度がよくなっても, 逆に定態安定度が悪くなることがある。 過渡安定度向上と定態安定度向上を同時に目的として制御 できないので，過渡安定度を向上させる目的で制御系を決 定した後に, 固有值の実部も負で定態安定度も維持されて いる潮流状態を確認するものとなっている。今後は，両安 定度向上を協調させるアルゴリズムを考える必要がある。

\section{6. おわりに}

3 つの代表的な託送ケースについてシミュレーションを 行った結果, UPFCの過渡安定度向上への効果が電気学会 東 10 機系統において確認できた。ATCの最大化に対して は非常に大きなインバー夕設置容量を必要とするが, 適切 な容量の UPFCで過渡安定度も考慮したATC の向上に大 きく寄与できることが分かった。

過渡安定度を向上するためにUPFC の操作变数 3 つのそ れぞれの制御系のゲインを微小変化させて CCT 感度を調 べて変更しているが，この手法では局所解に陥る可能性が 
ある。遺伝的アルゴリズムのような発見的手法を用いるこ とでより最適なゲインの值を決定できる可能性がある。

今後は複数の利害関係者が存在する中での ATC の取り扱 いについて FACTS 機器が与える影響も検討する必要があ る。また，他の FACTS 機器との比較や，ATC 向上を目的 に系統に導入した UPFC が供給信頼度に与える影響(12)に ついて検討したい。

(平成 18 年 2 月 22 日受付, 平成 18 年 5 月 12 日再受付)

\section{文献}

(1) M. Kato, Y. Morioka, Y. Nakahigashi, Y. Mishima, Y. Nakachi, M. Asada K. Tokuhara, M. Akamatsu, and M. Furuta: "Implementation of Unified Power Flow Controller and Verification for Transmission Capability Improvement", T. IEE Japan, Vol.118-B, No.10, pp.1194-1200 (1998-10) (in Japanese)

加藤正直 · 森岡靖夫 · 中東祐二 · 三島康弘 · 中地芳紀 - 浅田 実 · 徳原克久·赤松昌彦・古田通博: 「UPFC 縮小モデル開発と送電機能 向上効果の検証」, 電学論 B, 118, 10, pp.1194-1200 (1998-10)

(2) M. Hojo, D. Kamolyabutra, Y. Mitani, T. Ise, and K. Tsuji: "Experimental Study on Power System Stabilization by UPFC with Linearizeng Control of Power Swing", T. IEE Japan, Vol.120-B, No.2, pp.202-209 (2000-2) (in Japanese)

北篠昌秀· Duangkamol Kamolyabutra · 三谷康範 ·伊瀬敏史 · 辻毅一 郎：「UPFC を用いた電力動摇線形化に基づく系統安定化制御の実験 による検証」, 電学論 B, 120, 2, pp.202-209 (2000-2)

(3) R. Mihalic, P. Zunko, and D. Povh: "Improvement of transient stability using unified power flow controller", IEEE Trans. Power Delivery, Vol.11, No.1, pp.485-492 (1996-1)

(4) Y. Xiao, Y.H. Song, C. Liu, and Y.Z. Sun: "Available Transfer Capability Enhancement Using FACTS Devices", IEEE Trans. Power Syst., Vol.18, No.1, pp.305-312 (2003-2)

(5) K. Nishida and S. Iwamoto: "A Study on Improvement Effects of Stability ATC by TCSC", 2005 National Convention Record IEE Japan, No.6-091 (2005)

西田圭吾・岩本伸一：「TCSCによる安定度 ATC 向上効果に関する 考察」, 平成 17 年電気学会全国大会, No.6-091 (2005)

(6) H. Motoki and A. Yokoyama: "Study on Optimal Power Flow Control for ATC Enhancement by UPFC and its Performance Evaluation", Proc. of 2004 Annual Conference of Power \& Energy Society, IEE Japan, No.10 (2004) 元木啓明・横山明彦：「UPFCを用いた ATC 向上のための最適潮流 制御とその適用効果に関する研究」, 平成 16 年電気学会電力・エネ ルギー部門大会, No.10 (2004)

(7) X. Yu, C. Singh, S. Jakovljevic, D. Ristanovic, and G. Huang: "Total Transfer Capability Considering FACTS and Security Constraints", Proc. Transmission and Distribution Conference and Exposition 2003 IEEE PES, pp.73-78 (2003)

(8) T. Masuta and A. Yokoyama: "Application of UPFC to ATC Improvement Considering Transient Stability", Proc. of 2005 Annual Conference of Power \& Energy Society, IEE Japan, No.208 (2005)

益田泰輔・横山明彦：「ATC 確保のための UPFCによる過渡安定度 向上効果に関する研究」, 平成 17 年電気学会電力・エネルギー部門 大会, No.208 (2005)
(9) NERC web site: "http://www.nerc.com"

(10) S. Kozuma and A. Yokoyama: "Control System Design of Unified Power Flow Controller for Stability Enhancement in Multi-machine Power System", Proc. of 1999 Annual Conference of Power \& Energy Society, IEE Japan, No.222 (1999)

上妻周太郎・横山明彦：「UPFCによる多岐系統における安定度向上 効果」, 平成 11 年電気学会電力・エネルギー部門大会, No.222 (1999)

(11) T. Ishikawa, A. Yokoyama, Y. Kato, and T. Funakoshi: "Optimal Power Flow Control by UPFC Taking into Account Power System Stability”, Proc. of 2002 Annual Conference of Power \& Energy Society, IEE Japan, No.2 (2002)

石川鉄郎 ·横山明彦 ·加藤安紀・舟越節彦：「電力系統の安定度を考 慮した UPFCによる最適潮流制御」, 平成 14 年電気学会電力・エネ ルギー部門大会, No.2 (2002)

(12) R. Billinton, M. Fotuhi-Firuzabad, S.O. Faried, and S. Aboreshaid: "Impact of Unified Power Flow Controller on Power System Reliability”, IEEE Trans. Power Syst., Vol.15, No.1, pp.410-415 (2000-2)

益 田 泰 輔 (学生員) 1982 年 9 月 17 日生。 2005 年 3 月東

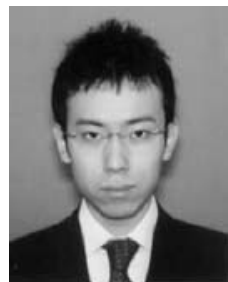
京大学工学部電気工学科卒業。同年 4 月東京大学 大学院工学系研究科電気工学専攻入学。現在，修 士課程に在学し，主にFACTS 機器に関する研究 に従事。

元木啓 明 (正員) 1978 年 6 月 29 日生。 2002 年 3 月東京

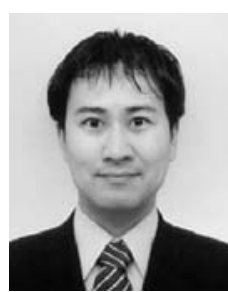
大学工学部電気工学科卒業。同年 4 月東京大学大 学院工学系研究科電気工学専攻入学。2004 年 3 月東京大学工学部電気工学科卒業。同年 4 月東京 電力 (株) 入社。現在に至る。

横 山 明 彦 (正員) 1956 年 10 月 9 日生。1979 年 3 月東京

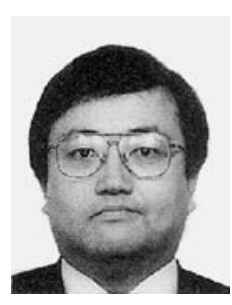
大学工学部電気工学科卒業。1981 年 3 月同大学 大学院工学系研究科電気工学専門課程修士課程修 了。1984 年 3 月同大学大学院工学系研究科電気 工学専門課程博士課程修了。工学博士。1984 年 4 月同大学工学部電気工学科助手。1985 年同講師。 1989 年同助教授。1995 年同大学大学院工学系研 究科電気工学専攻に配置換。2000 年 9 月同教授。 